\title{
ENTOMOLOGY
}

\section{Aphid diversity in two food legume crops: fava bean and pea in Naciria region, and first record of Melanaphis sacchari (Zehntner, 1897) in Algeria}

\author{
N. Bouabida, ${ }^{1}$ K. Benoufella-Kitous, ${ }^{1}$ S. Ait Amar, ${ }^{1}$ F. Medjdoub-Bensaad ${ }^{2}$ \\ ${ }^{1}$ Laboratory of Production, Improvement and Protection of Plants, Department of Animal and Plant Biology, Faculty \\ of Biological Sciences and Agronomic Sciences, Mouloud Mammeri University of Tizi-Ouzou; ${ }^{2}$ Production Laboratory, \\ Safeguard of Threatened Species and Crops, Influence of Climatic Variations, Faculty of Biological Sciences and \\ Agronomic Sciences, Mouloud Mammeri University of Tizi-Ouzou, Algeria
}

\begin{abstract}
Beans and peas are very important legumes because of their importance in human food and their high protein contents, as well as their role in the supply of atmospheric nitrogen to the soil. However, these crops are subject to various pest outbreaks, reducing their yield. The purpose of this study is to carry out an exhaustive inventory of aphids present on bean (Faba bean and Seville variety) and pea crops (Merveille De Kelvedone and Utrillo variety) in the region of Naciria (Boumerdes), in order to evaluate the diversity and abundance of aphids present in these crops. Sampling of aphid populations has been done using two trapping techniques: Barber pitfall trap and yellow traps. The results obtained express a richness of 48 aphid species, with one Melanaphis sacchari species identified for the first time in Algeria. 28 species are inventoried in the pea crop of Utrillo variety, 27 species on the Merveille de Kelvedone variety, 21 species
\end{abstract}

Correspondence: Karima Benoufella-Kitous, Laboratory of Production, Improvement and Protection of Plants, Department of Animal and Plant Biology, Faculty of Biological Sciences and Agronomic Sciences. Mouloud Mammeri University of Tizi-Ouzou 15000 Algeria.

E-mail: ben.kitous@yahoo.fr

Key words: Aphids, inventory, bean, pea, Naciria.

Contributions: The authors contributed equally.

Conflict of interest: The authors declare no potential conflict of interest.

Funding: None.

Received for publication: 14 November 2020.

Revision received: 24 December 2020

Accepted for publication: 8 January 2021.

${ }^{\circ}$ Copyright: the Author(s), 2020

Licensee PAGEPress, Italy

Journal of Entomological and Acarological Research 2020; 52:9503

doi:10.4081/jear.2020.9503

This article is distributed under the terms of the Creative Commons Attribution Noncommercial License (by-nc 4.0) which permits any noncommercial use, distribution, and reproduction in any medium, provided the original author(s) and source are credited. in the bean crop of Seville variety (Vicia faba major) and 20 species on the faba bean (Vicia faba minor).

\section{Introduction}

Food legumes are the basis of the human diet thanks to their nutritional interests and their high protein content. They also play a role in soil fertility through atmospheric nitrogen fixation (Schneider \& Huyghe, 2015). Unfortunately, these crops are infested by aphids causing a decrease in crop yields. They suck their hosts sap and inject saliva that could be phytotoxic causing wilting, yellowing and often death of plants. In addition, aphids are particularly damaging as vectors of plant disease viruses (Brault et al., 2010). They excrete a sticky substance "honeydew" on which fumagin develops decreasing the market value of the products (Eaton, 2016). In Algeria, few studies have been developed on aphids infesting food legumes (Laamari \& Hebbel, 2006 ; Benoufella-Kitous et al., 2014; Benoufella-Kitous \& MedjdoubBensaad, 2016; Benoufella-Kitous et al., 2019). There were no studies on legume aphids in the region of Naciria (Boumerdes). For this reason, an inventory of bean and pea aphids is managed to assess their diversity and abundance in this region.

\section{Materials and methods}

\section{Study area}

This study was carried out on fields of broad beans of Seville variety (Vicia faba var. major) and field bean variety (Vicia faba var. minor) and fields of peas of the Merveille de Kelvedone and Utrillo varieties during 2017-2018 crop year. The 4 study fields are located at an altitude of $158 \mathrm{~m}$ a.s.l. in the region of Naciria $\left(36^{\circ} 44^{\prime} 51\right.$ ' $N$, 3 $\left.{ }^{\circ} 49^{\prime} 44^{\prime \prime} \mathrm{E}\right)$, part of the province of Boumerdes, around $80 \mathrm{~km}$ East of Algiers (Figure 1) where the Mediterranean climate is characterized by a rainy and mild winter and a dry and hot summer. It must be emphasised that the fields did not undergo any phytosanitary treatment during the entire sampling period.

\section{Aphid trapping method}

Sampling was carried out over 13 weeks, from 26/01/2018 until the end of the crop on 20/04/2018. Each field was divided into nine 
homogeneous quadras. In the centre of each quadra, a Barber pot (20 $\mathrm{cm}$ in diameter by $10 \mathrm{~cm}$ high) and a yellow trap $(20 \mathrm{~cm}$ in diameter by $15 \mathrm{~cm}$ high) were placed. The yellow traps were placed on stakes $40 \mathrm{~cm}$ above the ground. Barber pots were placed in the ground.

The traps were filled with water to which was added a small amount of detergent to act as a wetting agent, reducing water surface tension and preventing trapped insects from escaping once caught (Benkhelil, 1992).

Aphid sampling and recovery were carried out on regular basis during weekly field trips. Collected aphids were preserved in $70 \%$ Ethanol, counted and then identified in the laboratory. Aphid identification was carried out based on the determination keys described by Jacky \& Bouchery (1982); Remaudière et al. (1985); Autrique \& Ntahimpera (1994); Blackman \& Eastop (2000, 2006).

\section{Exploitation of results}

Different analyses were applied in order to exploit the results obtained, namely the ecological indices composition (total richness and relative abundance), as well as the ecological indices structure (Shannon and Peilou equitability indices).

\section{Ecological composition indices}

\section{Specific richness}

The specific wealth is one of the fundamental parameters characteristic of a settlement. The total richness (S) of a biocenosis corresponds to the totality of species that make it up (Ramade, 1984).

\section{Relative abundance or percent frequency}

Relative abundance $(\mathrm{AR} \%)$ is the percentage of the number of individuals of a species (ni) in relation to the total number of individuals $(\mathrm{N})$ : $\mathrm{AR} \%=\mathrm{ni} \times 100 / \mathrm{N}$ (Faurie et al., 1980).

\section{Ecological indices structure}

\section{Shannon-Weaver Diversity Index}

This index provides information on the diversity of each environment under consideration. It varies both according to the number of species present and the abundance of each of them (Barbault, 2008). It is calculated using the following formula:

$$
\mathrm{H}^{\prime}=-\Sigma \text { qi } \log 2 \text { qi }
$$

H': Shannon-Weaver Diversity Index expressed in bit units. qi: Probability of occurrence of the species ( $q \mathrm{i}=\mathrm{ni} / \mathrm{N}$, where ni is the number of each species in the sample and $\mathrm{N}$ is the sum of the ni of all species combined).

Log2: logarithm - base 2 .

\section{Peilou equidistribution or equitability index (E)}

It is the relationship between real diversity and maximum theoretical diversity (Blondel, 1975).

$$
\mathrm{E}=\mathrm{H}^{\prime} / \mathrm{H}^{\prime} \max \text {. }
$$

H' is Shannon's diversity index expressed in bits.

$\mathrm{H}^{\prime}$ max. is the index of maximum diversity expressed in bits, with $\mathrm{H}^{\prime}$ max. $=\mathrm{H}^{\prime}$ / $\log 2$ where $\mathrm{S}$ is the total richness corresponding to the number of species present.

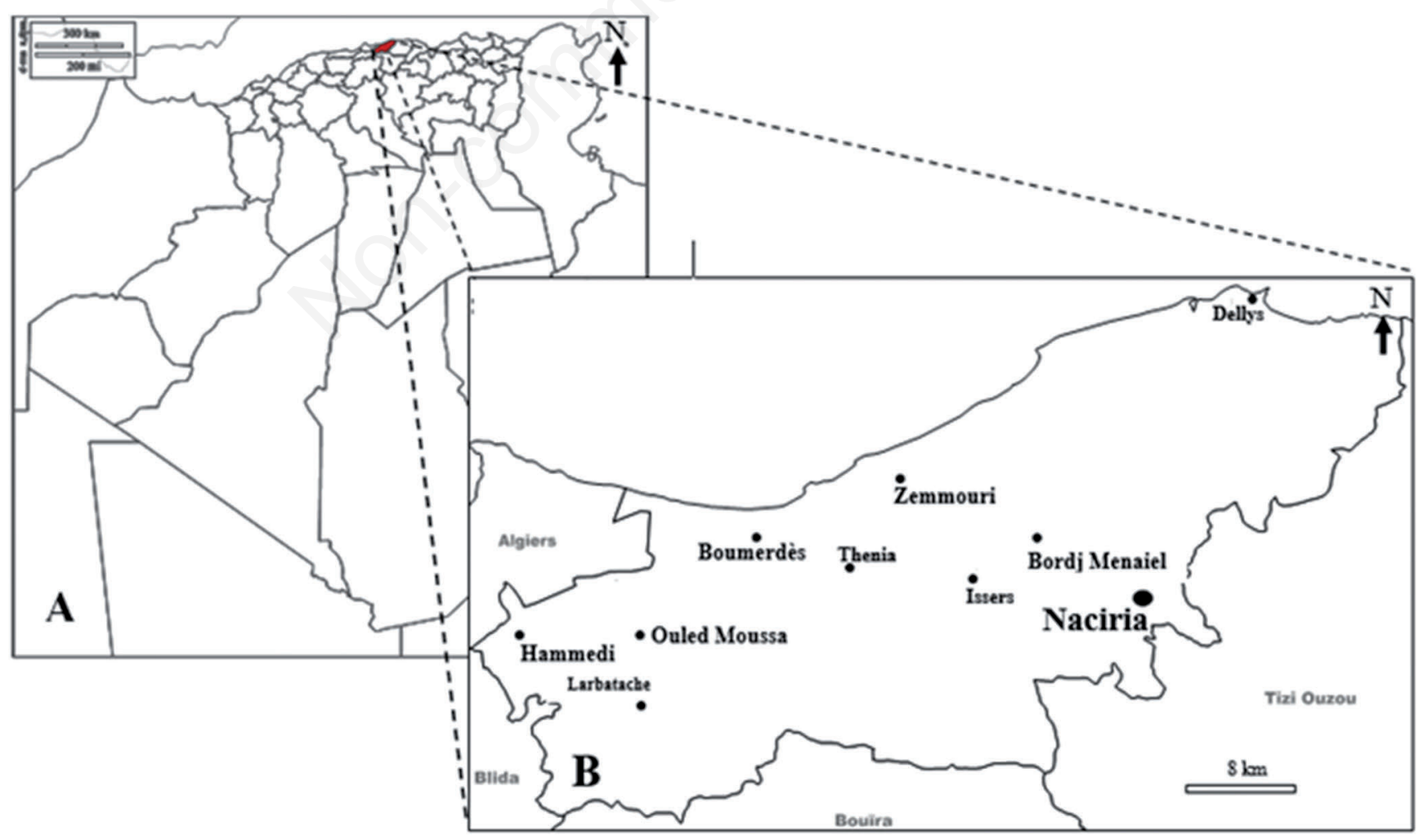

Figure 1. Map of Boumerdes region and location of study site, (A) Map of Algeria showing the study region, (B) the study region. 


\section{Results}

In this experimental study, trapping winged aphids using the yellow traps resulted in a list of aphids that could infest four field of food legumes.

\section{List of aphids found in the four legume fields: Seville bean, Faba bean, Merveille de Kelvedone pea and Utrillo pea}

Aphid fauna analysis in the four studied fields revealed the existence of 48 species of aphids: 28 species of aphids in the Utrillo pea crop and 27 species in the Merveille de Kelvedone variety; in the bean crop, 21 species were identified in the Seville variety field and 20 species in the broad bean variety.

Sampling made it possible to trap a new species that has never been identified in Algeria. It is M. sacchari trapped in the Utrillo field (Table 1).

\section{Percent frequency or relative abundance $(\%)$}

During the 13 weeks of trapping, 383 individuals were collected representing 48 species belonging to 21 genera, two tribes and a single subfamily, in the four study fields. The relative abundance of these species varied from one crop to another. A. gossypii and $M$. persicae were the most present species in the pea crop of Merveille de Kelvedone variety. A. gossypii was the most abundant in the Utrillo variety. A. fabae and A. gossypii were the most frequent in the two bean crops. The other species were poorly represented with frequencies ranging from $1.25 \%$ to $8.93 \%$ (Table 2).

\section{Ecological indices structure}

The results of the ecological structure indices applied to the species caught by different types of traps show that the highest Shannon diversity index value $\left(H^{\prime}=4.38\right.$ bits $)$ is observed in the Utrillo pea crop. This value varies between 3.66 and 3.92 bits for the other crops (Figure 2).
The maximum diversity H' max varies between 4.32 and 4.81 bits for all cultivated varieties. The equitability obtained tends towards 1 at the level of the 4 cultivated varieties.

\section{Discussion and conclusions}

Analysis of the aphid fauna in the four fields used for the study pointed out the presence of 48 aphid species. In Oued-Smar (Algiers, Algeria), Boussad \& Doumandji (2004) report that among the insects collected on a bean crop, the Aphididae family is the most representative with a total of 73 specimens. Working in Biskra (Algeria) region, Laamari \& Hebbel (2006) identified 16 aphid species in a field of $V$. faba. In 2014, Benoufella-Kitous et al. (2014) reported the presence of 27 species of aphids in a bean field in the region of Draâ Ben Khedda (Tizi-Ouzou, Algeria) inclusive of 125 specimens belonging to 25 species in 2008 and 143 specimens attributed to 19 species in 2013. In chickpea and lentil crops situated in Tala Amara (Tizi-Ouzou, Algeria), Benoufella-Kitous \& Medjdoub-Bensaad (2016) have identified 55 aphid species. The work of Lopes et al. (2012) in Belgium recorded the presence of 37 aphid species in a pea field. Singh et al. (2016) in a study on biodiversity of aphids infesting legumes in India, reported the presence of 73 species that could infest these crops. In 2019, Benoufella-Kitous et al. (2019) studied the aphid diversity of four food legumes (broad bean, chickpea, pea and lentil) in the region of Tizi-Ouzou. The results obtained by these authors showed the existence of 43 species of aphids.

Aphid species richness characterizing the investigated fields can be justified on the one hand by the climatic conditions favourable to aphid flight and on the other hand by the abundance and diversity of cultivated host plants and weeds likely to attract aphids. Hanski \& Cambefort (1991) assert that the richness of a stand depends on the level of available trophic resources and climatic conditions of the investigated biotopes. Indeed, the increase in plant diversity leads to an increase in the diversity of phy-

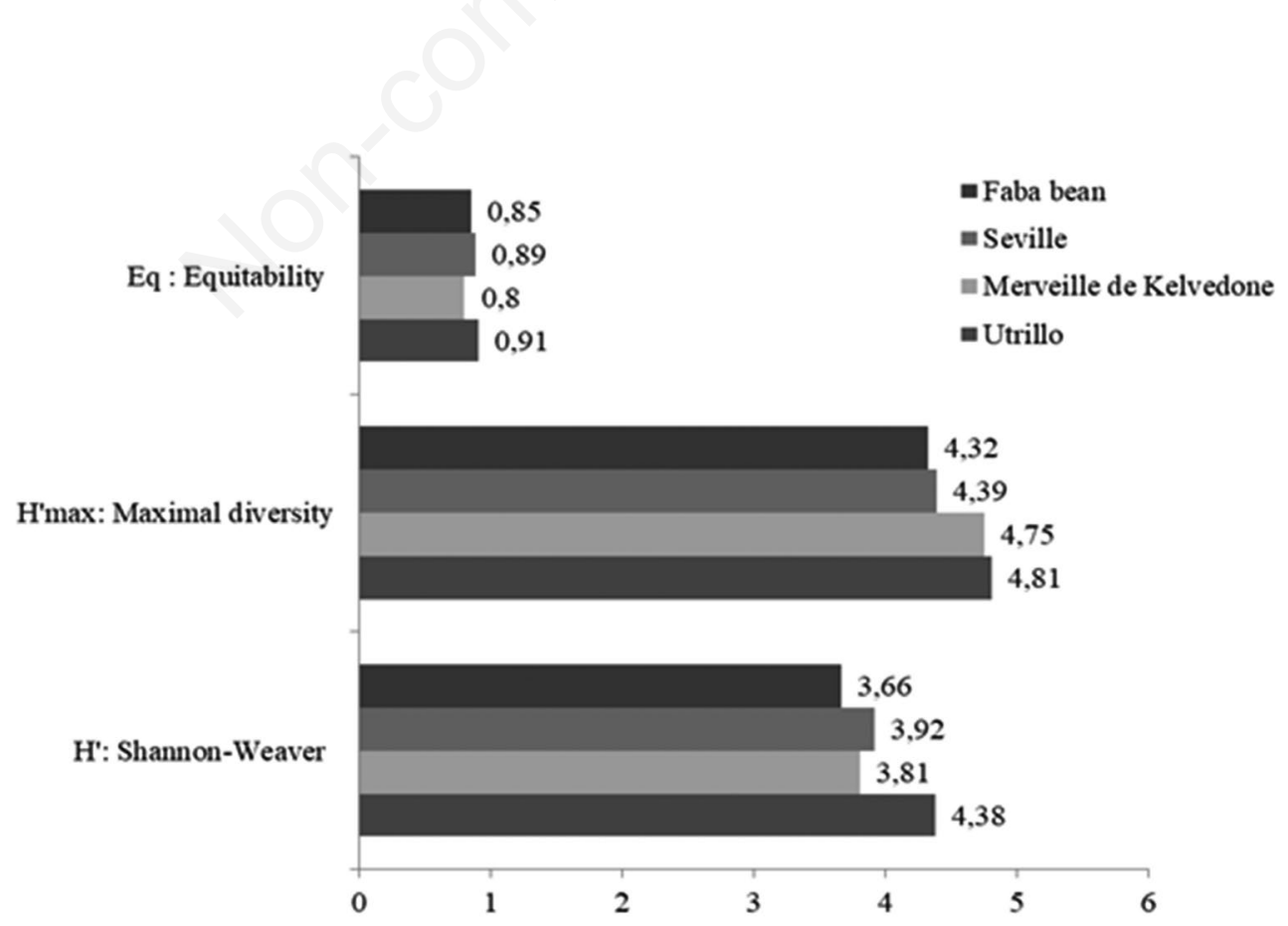

Figure 2. Shannon-Weaver index value for the different trapping techniques used for each cultivated plot. 
tophagous plants (Barbault, 1981). Wild plants are very often the additional source of winged aphids that will settle on receptive crops (Remaudière \& Autrique, 1984).

The analysis of the surveys shows that A. gossypii and M. persicae are the most frequent species in the pea field in Merveille de Kelvedone variety. In the Utrillo variety, $A$. gossypii is the most represented. In the two bean crops, two species are abundant: $A$. fabae and $A$. gossypii.

In a bean crop, Benoufella-Kitous et al. (2014) noted the presence of $A$. gossypii with a frequency of $9.3 \%$ of winged aphid species captured in 2008 and $16.1 \%$ in 2013. In Tunisia, this aphid

Table 1. List of aphids detected in the four food legume fields: bean (Seville variety, broad bean variety) and pea (Kelvedone variety, Utrillo variety) fields located in Naciria region (Boumerdes).

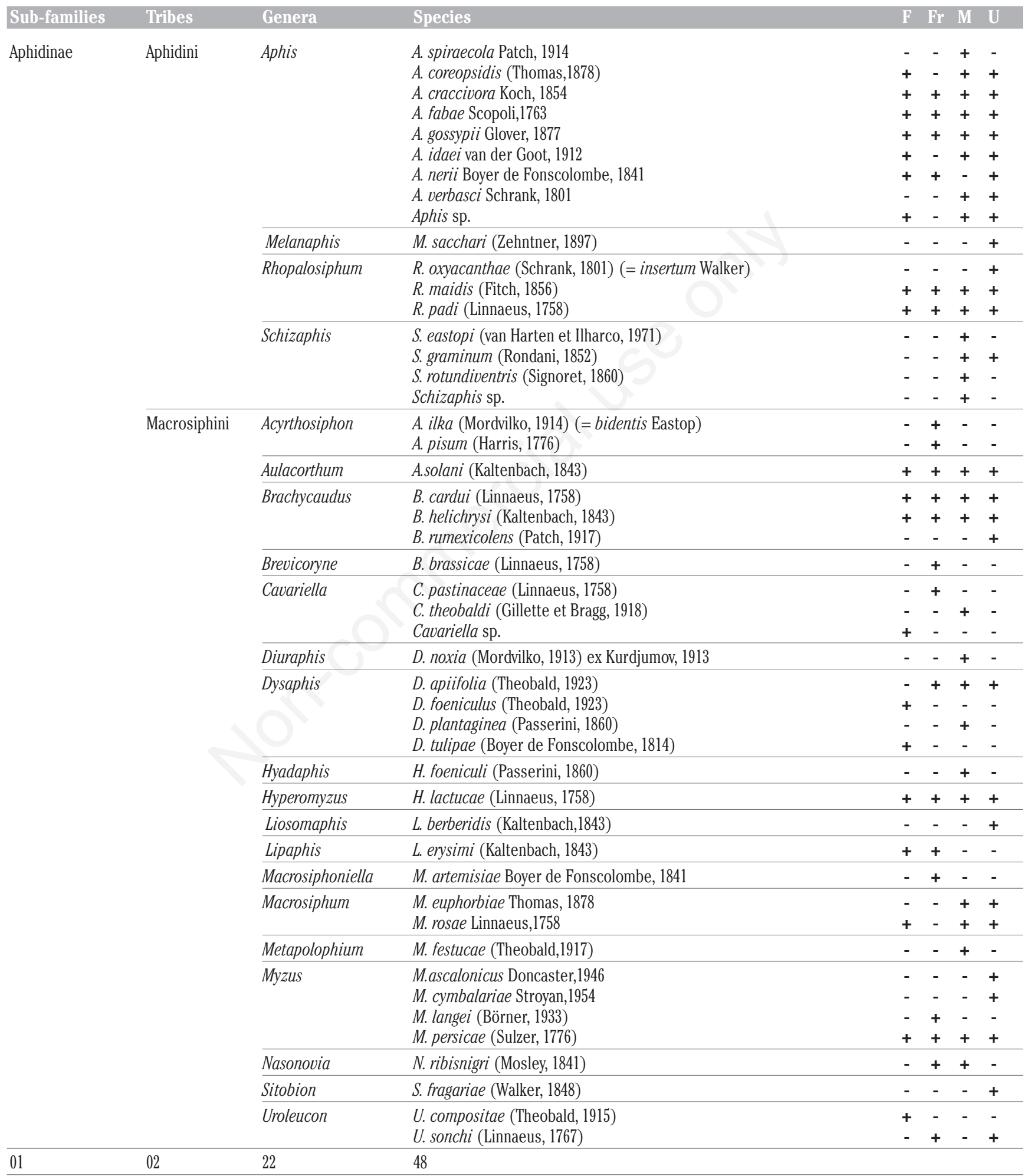

F: Bean Seville variety; Fr: Broad bean variety; K: Pea Merveille de Kelvedone2; U: Pea Utrillo; + : Presence ; - : Absence. 
Table 2. Values of centesimal frequencies (\%) applied to the different aphid species harvested in the crops studied.

\begin{tabular}{|c|c|c|c|c|c|c|c|c|}
\hline \multirow[t]{2}{*}{ Species } & \multicolumn{2}{|c|}{ Pea Merveille de Kelvedone } & \multicolumn{2}{|c|}{ Pea Utrillo } & \multicolumn{2}{|c|}{ Bean Seville variety } & \multicolumn{2}{|c|}{ Broad bean variety } \\
\hline & ni & AR\% & ni & AR\% & ni & $\mathbf{A R} \%$ & ni & AR\% \\
\hline A. craccivora & 9 & 4.79 & 4 & 5.06 & 3 & 5.36 & 6 & 10 \\
\hline A. fabae & 24 & 12.77 & 4 & 5.06 & 8 & 14.29 & 13 & 21.66 \\
\hline A. gossypii & 41 & 21.81 & 11 & 13.92 & 6 & 10.71 & 12 & 20 \\
\hline A. verbasci & 7 & 3.72 & 2 & 2.53 & 0 & 0 & 0 & 0 \\
\hline A. spiraecola & 3 & 1.59 & 0 & 0 & 0 & 0 & 0 & 0 \\
\hline A. idaei & 1 & 0.53 & 1 & 1.26 & 1 & 1.79 & 0 & 0 \\
\hline A. solani & 8 & 4.25 & 3 & 3.79 & 1 & 1.79 & 2 & 3.33 \\
\hline Aphis sp. & 7 & 3.72 & 1 & 1.26 & 1 & 1.79 & 0 & 0 \\
\hline A. ilka & 0 & 0 & 0 & 0 & 0 & 0 & 3 & 5 \\
\hline M. ascalonicus & 0 & 0 & 1 & 1.26 & 0 & 0 & 0 & 0 \\
\hline A. pisum & 0 & 0 & 0 & 0 & 0 & 0 & 2 & 3.33 \\
\hline A. nerii & 0 & 0 & 3 & 3.79 & 1 & 1.79 & 1 & 1.66 \\
\hline A. coreopsidis & 2 & 1.06 & 1 & 1.26 & 1 & 1.79 & 1 & 1.66 \\
\hline B.cardui & 1 & 0.53 & 2 & 2.53 & 2 & 3.57 & 2 & 3.33 \\
\hline B. helichrysi & 3 & 1.59 & 3 & 3.79 & 3 & 5.36 & 1 & 1.66 \\
\hline B. rumexicolens & 0 & 0 & 2 & 2.53 & 0 & 0 & 0 & 0 \\
\hline B. brassicae & 0 & 0 & 0 & 0 & 0 & 0 & 2 & 3.33 \\
\hline Cavariella sp. & 0 & 0 & 0 & 0 & 1 & 1.79 & 0 & 0 \\
\hline C. pastinaceae & 0 & 0 & 0 & 0 & 0 & 0 & 1 & 1.66 \\
\hline C. theobaldi & 1 & 0.53 & 0 & 0 & 0 & 0 & 0 & 0 \\
\hline D. apiifolia & 4 & 2.13 & 3 & 3.79 & 0 & 0 & 0 & 0 \\
\hline D. foeniculus & 0 & 0 & 0 & 0 & 1 & 1.79 & 0 & 0 \\
\hline D. tulipae & 0 & 0 & 0 & 0 & 1 & 1.79 & 0 & 0 \\
\hline D. plantaginea & 2 & 1.06 & 0 & 0 & 0 & 0 & 0 & 0 \\
\hline D. noxia & 1 & 0.53 & 0 & 0 & 0 & 0 & 0 & 0 \\
\hline H. lactucae & 11 & 5.85 & 8 & 10.12 & 5 & 8.93 & 2 & 3.33 \\
\hline H. foeniculi & 0 & 0 & 0 & 0 & 1 & 1.79 & 0 & 0 \\
\hline M. persicae & 29 & 15.41 & 9 & 11.39 & 7 & 12.5 & 5 & 8.33 \\
\hline M. langei & 0 & 0 & 0 & 0 & 0 & 0 & 1 & 1.66 \\
\hline M.euphorbiae & 2 & 1.06 & 3 & 3.79 & 0 & 0 & 0 & 0 \\
\hline M. rosae & 6 & 3.19 & 3 & 3.79 & 1 & 1.79 & 0 & 0 \\
\hline M. festucae & 1 & 0.53 & 0 & 0 & 0 & 0 & 0 & 0 \\
\hline M. sacchari & 0 & 0 & 1 & 1.26 & 0 & 0 & 0 & 0 \\
\hline M. cymbalariae & $\sqrt{x}$ & 0 & 1 & 1.26 & 0 & 0 & 0 & 0 \\
\hline N. ribisnigri & +2 & 0.53 & 0 & 0 & 0 & 0 & 1 & 1.66 \\
\hline R. padi & 13 & 6.91 & 3 & 3.79 & 5 & 8.93 & 0 & 0 \\
\hline R. maidis & 5 & 2.67 & 3 & 3.79 & 5 & 8.93 & 2 & 3.33 \\
\hline R. oxyacanthae & 0 & 0 & 3 & 3.79 & 0 & 0 & 0 & 0 \\
\hline L. erysimi & 0 & 0 & 0 & 0 & 1 & 1.79 & 1 & 1.66 \\
\hline L. berberidis & 0 & 0 & 1 & 1.26 & 0 & 0 & 0 & 0 \\
\hline S.rotundiventris & 1 & 0.53 & 0 & 0 & 0 & 0 & 0 & 0 \\
\hline Schizaphissp & 1 & 0.53 & 0 & 0 & 0 & & 0 & 0 \\
\hline S. eastopi & 1 & 0.53 & 0 & 0 & 0 & 0 & 0 & 0 \\
\hline S. graminum & 3 & 1.59 & 1 & 1.26 & 0 & 0 & 0 & 0 \\
\hline S. fragariae & 0 & 0 & 1 & 1.26 & 0 & 0 & 0 & 0 \\
\hline M. artemisiae & 0 & 0 & 0 & 0 & 0 & 0 & 1 & 1.66 \\
\hline U. sonchi & 0 & 0 & 1 & 1.26 & 0 & 0 & 1 & 1.66 \\
\hline U. compositae & 0 & 0 & 0 & 0 & 1 & 1.79 & 0 & 0 \\
\hline Total & 188 & 100 & 79 & 100 & 56 & 100 & 60 & 100 \\
\hline
\end{tabular}


is identified by Ben Halima-Kamel \& Ben Hamouda (1993) on eggplant, chilli pepper, cucumber and melon. This species is also reported by Vayssières et al. (2001) on Solanaceae, Cucurbits, Fabaceae and Asteraceae. On courgette crops, A. gossypii is in the vast majority with $99 \%$ of aphids identified on this crop (Lopes et al. 2012). Benoufella-Kitous (2015) reports the presence of this species in the form of low density colonies, apterous individuals on Avena sterilis L. and denser colonies on Lavatera cretica L. Sekkat (2015) reports it on Cucurbits, Solanaceae and Citrus in Morocco, whereas Singh et al. (2016) note the presence of A. gossypii on 39 legume species in India.

Mezani et al. (2016), in a study of invertebrate assessment on a bean field in the region of Tizi-Ouzou, show that $A$. fabae is the most dominant species in the yellow traps with 48 specimens representing a relative abundance of $17.84 \%$. The study carried out by Medjdoub-Bensaad et al. (2014) shows that A. fabae is the most represented species with a frequency of $23.1 \%$ in a bean field. Kheloul \& Medjdoub-Bensaad (2014a) mention that this species only totals $8.2 \%$ compared to all aphids trapped in a bean field.

Benoufella-Kitous et al. (2019) report that the species $A$. fabae is the most present with a frequency of $23.1 \%$ in a broad bean crop. Kheloul \& Medjdoub-Bensaad (2014b) highlight the presence of A. fabae on Rumex sp., Vicia sicula (Raf.) Guss., Sonchus sp. and Melilotus officinalis (L.) Pall. Alhmedi et al. (2007) note the presence of this aphid on wheat and peas. Laamari et al. (2010) report that this aphid is identified on about 15 plant species.

Myzus persicae has as primary hosts peaches and other Rosaceae of the genus Prunus and as secondary hosts Asteraceae, Brassicaceae, Apiaceae and Cucurbitaceae (Hullé et al. 1999). Vayssière et al. (2001) note it on Rumex abyssinicus, Euphorbia hirta, Solanum nigrum L., Cajanus cajan Millsp., Tropaeolum sp. and Callistephus sp. According to Laamari et al. (2011), M. persicae is identified on 16 plant species. M. persicae is caught by Sekkat (2015) on peach, pepper, potato, tomato and several weed species. According to this author, M. persicae is among the most feared aphid species and most frequently harmful to crops, requiring specific phytosanitary treatments.

It should be noted that in the present study, one species is identified for the first time in Algeria. It is Melanaphis sacchari, which is caught with a very low frequency $(1.26 \%)$.

The sugarcane aphid, M. sacchari is present in many African countries such as Angola, Egypt, Ethiopia, Nigeria, and Uganda. In Mexico, this species was first identified in 2013, in sorghum fields (Maya-Hernandez \& Rodriguez-Del-Bosque, 2014). In 2016, this aphid was reported for the first time as a pest on sorghum in North America (Bowling et al., 2016). Blackman \& Eastop (2000, 2006) report that this pest can also develop on grasses. According to Holman (2009), M. sacchari was observed on several species of Poaceae, Rosaceae, but also on Brassicaceae. The latter family was represented in the pea field (Utrillo variety) by a species namely Sinapis arvensis L., which could perhaps explain the presence of this species in the trap.

Shannon's diversity varies from one culture to another. In the present study, the specific richness and diversity of the flora provide favourable conditions for the settlement of aphids. In a study carried out by Medjdoub-Bensaad et al. (2014), Shannon diversity index calculated from fields of Seville bean and field bean is 0.75 and 0.69 bits respectively. Benoufella-Kitous et al. (2019) note that in chickpea, lentil and pea crops, H' values are 3.92, 3.88 and 0.32 bits respectively.

Equitability obtained tends towards 1 for the 4 cultivated varieties. This indicates that the numbers of the species present tend to be in equilibrium with each other.

According to Blondel (1975), when living conditions in an environment are favourable, many species are found. Aphid fauna is therefore diversified in the presence of the flora (Bassino, 1983). The density and diversity of insects are strongly influenced by the environment close to the crop field (Francis et al., 2001). Marc (2004) reports that winged specimens contribute in the dissemination of the population at variable distances and ensure the colonization of new habitats to be exploited.

Our study carried out on aphid diversity in four fields of bean and pea food legumes of two different varieties in Naciria region, shows the existence of 48 species of aphids with one species recorded for the first time in Algeria. This rather large number demonstrates the abundance of aphids on these crops. It would be edifying to continue this work for several years and on other crops to improve results.

\section{References}

ALHMEDI A., FRANCIS F., BODSON B., HAUBRUGE E. 2007 - Evaluation de la diversité des pucerons et de leurs ennemis naturels en grandes cultures à proximité de parcelles d'orties. Notes Faun. Gembloux 60: 147-152.

AUTRIQUE A., NTAHIMPERA X. 1994 - Atlas des principales espèces de pucerons rencontrées en Afrique Sud-sahariennes. Administration Générale de la Coopération au Développement (A.G.C.D.), Bruxelles. 78 pp.

BARBAULT R. 1981 - Ecologie des populations et des peuplements. Masson, Paris. 200 pp.

BARBAULT R. 2008 - Écologie générale: structure et fonctionnement de la biosphère. Dunod, Paris. 390 pp.

BASSINO J.P. 1983 - Influence des techniques de cultures en verger : notes de synthèse, faune et flore auxiliaire en agriculture. Journées d'Etude et d'Information, 4-5 mars, Paris 289-293.

BEN HALIMA-KAMEL M., BEN HAMOUDA M.H. 1993- Les pucerons des cultures protégées et leurs ennemis naturels. Tropicultura 11: 50-53.

BENKHELIL M.L. 1991 - Les techniques de récoltes et de piégeage utilisées en entomologie terrestre. - Office des Publications Universitaires, Alger. 68 pp.

BENOUFELLA-KITOUS K. 2015 - Bioécologie des pucerons de différentes cultures et de leurs ennemis naturels à Oued-Aissi et Draâ Ben Khedda (Tizi-Ouzou). Thèse de Doctorat. Ecole Nationale Supérieure d'Agronomie, El Harrach, Alger. 334 pp.

BENOUFELLA-KITOUS K., DOUMANDJI S., MEDJDOUB F. 2014 - Interest and place of three Vicia faba Aphid species in Draa Ben Khedda (Great Kabylia, Algeria). - Int. J. Agric. Res. 4: $27-36$.

BENOUFELLA-KITOUS K., MEDJDOUB-BENSAAD F. 2016 Aphids' diversity in chickpea (Cicer arietinum) and lentil (Lens culinaris) cultures within Tala Amara region (TiziOuzou, Algeria). - Adv. Environ. Biol 10: 19-29.

BENOUFELLA-KITOUS K., MEDJDOUB-BENSAAD F., KHELOUL L. 2019 - Diversité des pucerons des légumineuses alimentaires dans la région de Tizi-Ouzou. - Faun. Entomol. 72: 5-12.

BLACKMAN R.L., EASTOP V.F. 2000 - Aphids on the World's crops. An identification and information guide. 2nd edition, The Natural History Museum, Wiley, Chichester, UK. $466 \mathrm{pp}$.

BLACKMAN R.L., EASTOP V.F. 2006 - Aphids on the World's herbaceous plants and shrubs. The Natural History Museum, Wiley, Chichester, UK.1439 pp.

BLONDEL J. 1975 - L'analyse des peuplements d'oiseaux-élé- 
ments d'un diagnostic écologique. La méthode des échantillonnages fréquentiels progressif (E. F. P.). - Rev. Ecolog. 29: 533-589.

BOUSSAD F., DOUMANDJI S.D. 2004 - Inventaire et dégâts dus aux insectes sur quatre Variétés de la fève à l'institut technique des grandes cultures d'Oued-Smar. 5ème journée scientifique et techniques phytosanitaire 15-16 Juin 2004.

BOWLING R.D., BREWER M.J., KERNS D.L., GORDY J., SEITER N., ELLIOTT N.E., BUNTIN G.D., WAY M.O., ROYER T.A., BILES S., MAXSON E. 2016 - Sugarcane aphid (Hemiptera: Aphididae): a new pest on sorghum in North America. - J. Integr. Pest Manag. 7: 1-13.

BRAULT V., UZEST M., MONSION B., JACQUOT E., BLANC S. 2010 - Aphids as transport devices for plant viruses. - C. R. Biol. 333: 524-538.

EATON A.T. 2016 - Aphids. Pest Fact Sheet 19. (UNH) Cooperative Extension. 3 pp.

FAURIE C., FERRA C., MEDORI P., DEVAUX J., 1980 - Ecologie approche scientifique et pratique. Lavoisier, Paris $488 \mathrm{pp}$.

FRANCIS F., COLIGNON P., HASTIR P., HAUBRUGE E., GASPAR C. 2001 - Evaluation of aphidophagous ladybird populations in a vegetable crop and implications as biological control. - Medical Faculty Landbouw University Gent 66: 333-340.

HANSKI I., CAMBEFORT Y. 1991 - Dung beetle ecology. Princeton University Press, Princeton, New Jersey. 493 pp.

HOLMAN J. 2009 - Host Plant catalog of aphids: Palaearctic region. Springer Verlag, New York, USA. 1216 pp.

HULLÉ M., IGHIL E.T.A., ROBERT Y., MONNET Y. 1999 - Les pucerons des plantes maraîchères. Cycles biologiques et activités de vol. Institut National Recherche Agronomique, Paris. 136 pp.

JACKY F., BOUCHERY Y. 1982 - Atlas des formes ailées des espèces courantes de pucerons. Institut National Recherche Agronomique, Colmar. $48 \mathrm{pp}$.

KHELOUL L., MEDJDOUB-BENSAAD F. 2014a - Inventaire qualitatif et quantitatif des pucerons inféodés à la culture de la féverole Vicia faba minor dans la région de Tizi- Rached (TiziOuzou). Séminaire Nationale biodiversité faunistique 7-9 décembre 2014, Alger.

KHELOUL L., MEDJDOUB-BENSAAD F. 2014b - Inventaire qualitatif et quantitatif des pucerons inféodés à la culture de la féve Vicia faba major variété Séville dans la région de TiziRached (Tizi-Ouzou). $1^{\text {er }}$ Congrès maghrébin sur la Biodiversité, la Protection des milieux naturels écodéveloppement 16 et 17 décembre 2014, Sidi Bel Abbes.

LAAMARI M., HEBBEL S. 2006 - Les principaux insectes ravageurs de la fève dans une région de Biskra. - Rech. Agronom. 18: 72-78.

LAAMARI M., JOUSSELIN E., COEUR D'ACIER A. 2010 Assessment of aphid diversity (Hemiptera: Aphididae) in Algeria: a fourteen-year investigation. - Faun. Entomol. 62: 73-87.
LAAMARI M., TAHAR CHAOUCHE S., BENFERHAT S., AABBES B., MEROUANI H., GHODBANE S., KHENISSA N., STARY P. 2011 - Interactions tritrophiques: Plante-PuceronsHyménoptère Parasitoïde observées en milieux naturels et cultivés de l'Est algérien - Faun. Entomol. 63: 115-120.

LOPES T., BOSQUEE E., POLO LOZANO D., CHEN J.L., CHENG DENGFA C., YONG L., FANG-QIANZ Z., HAUBRUGE E., BRAGARD C., FANCIS F. 2012 Evaluation de la diversité des pucerons et de leurs ennemis naturels en cultures maraichées dans l'est de la chine. - Faun. Entomol. 64: 63-71.

MARC P. 2004 - Les pucerons. Dossier Technique 2. - Asbl. Adalia: 1-6.

MAYA-HERNANDEZ V., RODRIGUEZ-DEL-BOSQUE L.A. 2014 - Pulgón amarillo: una nueva plaga del sorgo en Tamaulipas. Desplegable para productores No MX-0310301-32-03-13-48-30. INIFAP, Centro de Investigación Regional Noreste Campo Experimental Río Bravo, Tamaulipas, México. 2 pp.

MEDJDOUB-BENSAAD F., KHELOUL L., BENOUFELLAKITOUS K. 2014 - Diversité aphidienne au niveau des cultures de fève Vicia faba major et Vicia faba minor dans la région TiziOuzou. Séminaire Nationale biodiversité faunistique 7-9 décembre 2014, Alger.

MEZANI S., KHELFANE-GOUCEM K., MEDJDOUB-BENSAAD F. 2016 - Evaluation de la diversité des invertébrés dans une parcelle de fève (Vicia faba major) dans la région de TiziOuzou en Algérie. - Zool. Ecol. 26: 129-133.

RAMADE F. 1984 - Eléments d'écologie-écologie fondamental. Mc Graw-Hill, Paris. 397 pp.

REMAUDIERE G., AUTRIQUE A. 1984 - Contribution à l'écologie des aphides africains. Food Alimentary Organisation, Paris. $64 \mathrm{pp}$.

REMAUDIERE G., AUTRIQUE A., EASTOP V.F., STARY P., AYMONIN G. 1985 -Contribution à l'écologie des aphides africains. Organisation Nations Unies Alimentation Agriculture, Rome. 214 pp.

SCHNEIDER A., HUYGHE C. 2015 - Les légumineuses pour des systèmes agricoles et alimentaires durables. Quae, Paris. 473 pp.

SEKKAT A. 2015 - Les pucerons du Maroc: abrégé bioécologique des espèces évoluant sur les cultures. Aphids of Morocco: abridged bio-ecology of species evolving on crops. - Rev. Maroc. Protect. Plantes 7: 1-23.

SINGH R., SINGH G., SINGH K., SHARMA A. 2016 Biodiversity of Aphids (Insecta: Homoptera: Aphididae) Infesting Legumes (Angiospermae: Fabales: Fabaceae) in India. - IJRSZ 2: 30-44.

VAYSSIERES J.F., DELVARE G., MALDES J.M., ABERLENG H.P. 2001- Inventaire préliminaire des arthropodes des cultures maraichères sur 1'Ile de la Réunion. - Insect Sci. Applicat. 21: 1-22. 